\title{
On the reconstruction of some tense/aspect markers in Proto-Mande
}

\begin{abstract}
The paper discusses the origins and diachronic development of predicative markers of tense / aspect, mood and negation in the languages of the Mande family (West Africa). The analysis contains a survey of hypotheses regarding the genesis of the structure of verbal clauses in Mande from a typological standpoint, as well as a tentative reconstruction of some of the Proto-Mande predicative markers or their lexical sources.
\end{abstract}

Keywords: Mande, Niger-Congo, verbal system, TAM marking, predication, negation marking, comparative research, reconstruction.

\section{Introduction}

In the present article, an approach is made towards the reconstruction of several elements of the verbal grammar in the proto-language of the Mande language family. Structurally, it will consist of roughly two sections: a discussion on the reconstruction of syntactic patterns of the verbal clause in Proto-Mande, and a proposal on certain verbal markers of tense/aspect, modality, and polarity, which may be postulated for Proto-Mande. The article is by no means a full-fledged reconstruction of the system of grammatical marking on the verb in the proto-language; I would rather view the stage of my research which I am describing below as collecting most reliable and promising comparanda and building up initial hypotheses for further analysis.

Any comparative research is built on a thoroughly balanced sample of languages, carefully chosen from all major branches of the genetic stock. To justify the Proto-Mande nomination, any proposed reconstruction should find support in the two major branches, Eastern and Western; this binary division at the root is not disputed by any of the present-day scholars I know of. However, the predicative markers that we are dealing with are mostly characterised by very limited length: from 1 to 2 phonemes, more rarely 3 to 4 phonemes. In order to compare such short items, it is highly advisable to provide cognate forms and corresponding meanings in no less than two to three groups of each branch. The tonal patterns of the compared forms must also be taken into account, and tonal differences should be explained. According to the most recent classification by Vydrin [2009a], the Eastern branch encompasses Bisa-San, Boko-Busa, and Southern groups; the Western one is comprised of Manden, Mokole, South-Western, Vai-Kono, Soso-Jalonke, Soninke-Bozo, Samogo, and Bobo groups.

\section{Mande verbal system reconstruction: state of the art}

The task of reconstructing the verbal system of the Proto-Mande language ${ }^{1}$ is certainly on the agenda of contemporary comparative studies in this language family. Rebuilding of any

\footnotetext{
${ }^{1}$ This paper is elaborated within the framework of the international project "Proto-Niger-Congo: Comparison and Reconstruction" (http://www.nigercongo.com). 
proto-language starts with a thorough system of regular phonetic correspondences, as a prerequisite of morphological, syntactic or lexical conclusions. This is exactly what was initiated in the second half of the twentieth century: three major works published in the 1970s [Long 1971; Поздняков 1978; Bimson 1978] dealt with the reconstruction of the phonological system of the proto-language (even though two of them, namely Long's and Bimson's, only considered the Western branch of the family). Later, additional reconstructions of the proto-language consonantism were proposed by Grégoire [1988], Kastenholz [1996], and, for certain groups of languages within Mande, by Vydrin [2006a, 2007] and Schreiber [2008].

More recently, some papers devoted to the reconstruction of elements of morphosyntax have emerged. Vydrin [2006b] worked with plural marking and elements of nominal classification. Dwyer [1987-88] attempted to reconstruct the proto-language nominal derivational affixes and the system of numerals. There is an upcoming paper presenting an initial step in reconstructing Proto-Mande person markers [Babaev, in press].

In the meantime, the verbal system has enjoyed considerably less attention on the part of comparative linguists.

A complete reconstruction of the verbal system of a proto-language would certainly include both the morphosyntactic and the lexical levels. To be even more precise, such a reconstruction for Proto-Mande would require the analysis of the complex of the following subdomains:

1. The syntax of the clause and the verb phrase (VP).

2. The expression of grammatical meanings of the verb, more specifically, tense, aspect, modality, and polarity.

3. The marking of person, number, and possibly other categories of the verb's arguments, in case this marking is made on the verb or overlaps somehow with verbal categories proper.

4. Argument derivation, i. e. the formation of grammatical meanings by means of a shift of the verb's arguments (passivisation, causativisation, etc.).

5. Word formation, including reduplication, affixal derivation and nominalisation of the verb.

The first issue out of these five has been widely discussed in recent decades. Scholars were concerned with the origins of the syntactic system of the verbal clause in Mande, in general, and the origins of predicative markers as a specific category indicating temporal, aspectual, and modal meanings of the predicate, in particular (see section 3 for more details on this). At the same time, the projection of the phonetic shape and meanings of the predicative markers as lexical items, as well as verbal derivation morphemes, onto the Proto-Mande level was only briefly touched upon in the literature.

Research in this field has become easier with the recent breakthrough in both descriptive and typological (synchronic as well as diachronic) research on the languages of West Africa. Within the Mande family, we have observed the appearance of more and more grammars and manuals, mostly for the languages of Manden, Mokole, Jogo-Jeri, Southern, and South-Western groups. More and more papers are written in accordance with the modern criteria for quality grammar descriptions, accompanied with tone-marking and extensive textual material, which allow to penetrate deeper into the analysis of the morphosyntax. For external comparison purposes, a number of research works have emerged recently, analysing the diachronic development and synchronic state of TAM systems of various language families within Niger-Congo, including Bantu [Nurse 2007], Benue-Congo [Anyanwu 2010], Kwa [Ameka \& Kropp Dakubu 2008], and Kru [Marchese 1986]. Typology of verbal grammatical categories of tense and aspect 
is the focus of at least three recent collections of papers: [Heine \& Nurse 2000; Creissels 2005; Heine \& Nurse 2008].

\section{Syntax of the verbal clause and syntactic origins of predicative markers}

The Mande languages share the predominantly isolated type of syntactic structure, with only a slight injection of agglutination and concatenation. This leads to the fact that reconstructing verbal morphology means no less than reconstructing the syntax of the clause, since most of the verbal grammar is expressed by unbound elements within the analytic construction or the whole clause. Such elements, expressing the grammatical meanings of the predicate of the clause, will be called predicative markers ${ }^{2}$ in the present paper.

The basic word order in Mande is S-O-V-X, where X stands for indirect oblique objects of the verb, expressed by postposition phrases. Mande languages avoid double direct object marking, so there may be only one object noun phrase (NP) preceding the predicate.

Moreover, as Tröbs [2003] rightly states for Manden, the generation of complex analytic constructions all over the Mande family is cyclic: an older construction is constantly growing obsolete, replaced by a newer one, and at some stage they coexist in the language.

There are three positions within the clause where predicative markers can be situated. Within the basic word order scheme, these positions are marked by figures:

\begin{tabular}{l|l|l|l|l|l|}
\hline $\mathbf{1})$ & $\mathrm{S}$ & $\mathbf{( 2 )}$ & $\mathrm{O}$ & $\mathrm{V}$ & $\mathbf{( 3 )}$ \\
\hline
\end{tabular}

Each of the three types of predicative markers can serve as the sole expressor of the verbal meanings:

1) initial markers (IMs), cf. in Mwan:

(1) Bāā ̀̀ gē làkrùù wà béč $m \bar{\varepsilon} \bar{\varepsilon}$ bō sró

OPT 3SG go school village and people stay calm

'Let her go to school, and the people will take rest' [Perekhvalskaya 2006].

2) post-subject markers (PSMs), cf. in Zialo:

(2) Gà wò nì-jè-y nغ̀nغ̀

1SG PROSP 1SG-mother-DEF greet

'I will greet my mom' [Babaev 2011: 124].

3) post-predicate markers (PPMs), cf. in Bambara:

(3) Wárábilé-nù dòn-nà dá fè

monkey-PL penetrate-PFT door/DEF through

'Monkeys penetrated through the door' [Vydrin 2008].

In most languages at least some of the meanings are expressed by a combination of two markers in different positions; below, I will pay more attention to this phenomenon.

${ }^{2} \mathrm{Cf}$. other synonymous terms across the literature: construction markers, verbal auxiliaries, predicate markers, etc. 
The inventory of TAM meanings of the verb in Mande is not too extensive. There is a well known lack of a distinct boundary between aspect and tense, characteristic of most families of African languages [Fleisch 2000]. In most Mande languages, tense as a grammatical category seems to play a more marginal role in the verbal system, and one should rather see the latter as a system of aspectual oppositions, each of which has a link to a particular time plan. For instance, the prospective aspect presumes future action, the perfective is connected with the past, and the resultative links the past action with its result in the present.

Just as probably everywhere in West Africa, the basic aspectual opposition lies between imperfective and perfective aspects. Both terms in fact encompass clusters of meanings: the perfective aspect in most cases includes punctive action in the past and the completive (resultative) meaning of an action which ended in the past but also impacts the present. The peculiar «factative» aspect which denotes (a) past time for verbs expressing action and present, (b) undefined time for verbs expressing state [Welmers 1973] also lies within the domain of the perfective. The imperfective aspect may include progressive, habitual and future action; the last one is often called the prospective aspect in this regard, denoting the nearest, highly probable future action.

The most widespread modal meanings include the irrealis, whose typology has yet to be analysed in depth: habitually, it encompasses the distant future, the potential and conditional moods, as well as varieties of the negative polarity (often with the addition of a specific negation marker). The other modal forms witnessed across the family are the imperative, the prohibitive and the optative, though the last one occurs considerably rarer.

\subsection{Initial predicative markers}

The initial predicative markers constitute the least studied group - probably due to their being relatively rare. In fact, I have only spotted them in a few languages of the Southern group and one language of the South-Western group (Loko). In this latter language, there are two IMs, identical in segmental shape but differing by tone:

$\begin{array}{llll}\text { (4) Ká } & \text { tí hélé } & \text { ló-à } \\ \text { AOR } & \text { 3PL } & \text { elephant } & \text { see-RES }\end{array}$

'They saw an elephant' [Kimball 1983: 47]

(5) Kà ygúlú-ná í gúlà

IPF treeDEF 3SG fall

'The tree was falling' [Kimball 1983: 50].

The high-tone morpheme ká marks the aorist; the verb is also modified by the perfective PPM -àl-ngà. The low-tone kà is a marker that serves two purposes: it indicates the imperfect, i. e. either a past progressive or past habitual action, and (with a different series of person markers) the optative mood. The modal usage of this morpheme has parallels among the other representations of IMs, notably in Southern Mande. In fact, the Mwan language only uses the IM $b \bar{a} \bar{a}$ in modal utterances, see (1) above. A similar IM of modality is observed in the neighbouring Kru languages, cf. in Grebo:

$\begin{array}{lll}B-a & d u & n \grave{\varepsilon} \\ \text { HORT-1PL } & \text { измельчать } & \text { 3SG }\end{array}$

'Let us pound it' [Marchese 1986: 24-25]. 
The whole construction may be interpreted as one complex sentence with two clauses: the main one, represented by the single verb in the imperative, and a subordinate one. Such multiclausal optative sentence structures are widely witnessed cross-linguistically, cf. English Let me take you down or Russian Пусть это вас больше не тревожит 'Let it not disturb you anymore'. The optative meaning is often expressed by a subjunctive form of the verb, cf. Latin Sit fur at est bonus imperator 'Let him be a thief, but he's a good emperor'.

If we accept this hypothetical suggestion, the Loko IMs may potentially be associated with the South-Western Mande verb *ká 'to see, to do, to be' (Kpelle káa, Looma kà, Mende ká) [Leidenforst \& McKay 2005: 67; Prost 1967: 159; Innes 1969: 37], which has some external parallels, cf. Bozo (Jenaama) kay 'see' [Vydrin 2009a: 137]. The low tone of the optative/imperfect marker in Loko may be explained by the subjunctive semantics: indeed, in South-Western Mande we observe a proto-language variation in tone between markers of the 3rd person in main and subordinate clauses. Since kà was originally a verb, it had to be a finite form, so the incorporation of a tonal person marker (either high tone for aorist or low tone for optative / imperfect) seems natural.

A modal origin of TA markers in the initial position in the clause is further confirmed by markers of the prohibitive mood. In Guro (Southern Mande), the same IM is used to indicate prohibition and the subjunctive mood with a negative polarity (both require an additional PPM):

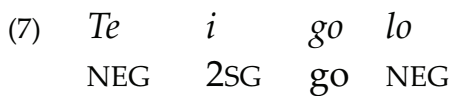

'Do not go!';

(8) Te é we míni lo

NEG 3SG wine drink NEG

'(I wish) he does not drink wine' [Benoist 1969: 68].

Concerning the origin of the Guro IM, I support the verbal etymology, see details on Proto-Mande *té below.

\subsection{Post-subject predicative markers and nomino-periphrastic constructions}

PSMs are the most widespread markers of verbal meanings in Mande languages, and probably the ones that are most discussed in the literature. Syntactically, they almost exclusively serve as proclitics, not in relation to the verb itself, but to the verb phrase, allowing the direct object to separate them from the predicate. This position is also used by person markers in those Mande languages where they constitute a category distinct from personal pronouns (see [Creissels 2005] for more details), cf. in Looma (South-Western):

(9) Fòlòmò jà vá

Folomo 3SG come

'Folomo will come' [Sadler 2006: 63].

There is a clear tendency across the Mande languages to avoid series of PSMs: the language prefers to merge them into a fused portmanteau marker which, consequently, expresses the whole set of grammatical meanings for both the predicate and its key arguments. The verb itself often remains in its base form, cf. in Mende (South-Western): 
(10) Ngćè ná wié siná

1SG that do tomorrow

'I will not do it tomorrow' [Innes 1971: 151].

This cumulation technique has led to the peculiar system of person marking in some of the groups of the family (Southern, Eastern, South-Western), where person markers form over a dozen of series bearing different temporal, aspectual and modal meanings (as well as polarity indication); they are generated by the incorporation within of former clitical TAM markers.

In some of the languages where two PSMs are still present, one can observe their fusion in fast colloquial speech or in dialects.

It is crucial that in a vast number of languages of the family the verbal meanings are expressed not by a sole PSM, but rather by a stable combination of one PSM and one PPM, so that the whole construction has the shape of the following example from Looma:

(11) Nà fà sà vàà zù

3SG PSM now come PPM

'He is coming now' [Sadler 2006: 63].

Just as mentioned above, the origins and the syntactic status of PSMs of tense/aspect and modality have been widely discussed in the literature. One of the first ideas of their etymology was brought in [Heine \& Reh 1984] who argued that the constructions similar in structure to that of (11) demonstrate the result of grammaticalisation of formerly full-fledged verbs. In the zenith of the grammaticalisation theory, this point of view was fully supported in several articles by Claudi [Claudi \& Mendel 1991; Claudi 1994]. The claim made by this "verbal" theory of the genesis of PSM was, upon first glance, quite logical: it proposed a gradual loss of lexical status of full-fledged verbs, first turning into auxiliary verbs, and then into unchangeable predicative markers. Originally these verbs were followed by NPs headed by nouns of action, which were later reinterpreted as proper verbs. As for the PPM sometimes occurring at the closure of the whole construction, that was an original noun of locative semantics ("locative noun", as Heine \& Reh [1984: 209f.] tend to call it). The whole transformation, according to this theory, must have looked like this (where VNP is verbal noun phrase):

(I)

(II)

$S$
$\downarrow$
$S$

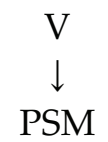

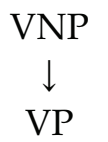

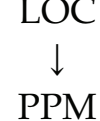

In the case when verbal noun represents transitive semantics, the VNP will include a direct object, even though the whole VNP is the direct object itself for the original verb in (I). But, the object within the VNP will be reconsidered as the direct object of the "new" verb in (II).

The idea looks especially appealing for such constructions as the progressive aspect, cf. an example from Kono [Claudi 1994: 214]:
Tambá غ̀
musu yan-dà
Tamba 3sG.be.at wife look.for-LOC
'Tamba is looking for a wife', lit. 'Tamba is at wife-looking'. 
The stage of grammaticalisation where the auxiliary has not yet lost its ability to attach TA markers is also widely witnessed, most evidently in progressive and prospective constructions; cf. two more examples from Kono:

(13) Ḿbé tá-à fítoy

1SG.PROG go-PROG Freetown

'I am going to Freetown';

(14) $\grave{\varepsilon}$ tá-à à dyánué-à

3SG.PROG go-PROG 3SG friend.DEF-LOC

'She is going to her friend' [Claudi 1994: 200].

Accepting the origin of this type of analytic constructions from such a periphrasis, one should admit that the original word order at some stage of the proto-language was SVO, with the object represented by a VNP. This is exactly the conclusion that Claudi and her colleagues come to, stating that this

"development as outlined for Mande is responsible for all synchronically existent cases of SOV order in Niger-Congo" [Claudi 1994: 218].

In Mande, some of the most widespread PSMs are indeed most easily etymologised from full-fledged verbs still in use in the language, cf. an example from Boko (Eastern Mande):

(15) Wá su mó

1PL FUT come

'We will come' [Prost 1976: 199], where su is derived from su/sua 'come, return' [Jones 2004a: 279].

Such processes are not always restricted to the prehistoric stage of language development: some contemporary tongues of the family demonstrate fairly recent progressive and prospective expressions generated from the same nomino-periphrastic constructions, cf. an example from Looma (South-Western Mande):

(16) Fòlòmò fà zà vàà zù

Folomo COP today come PP

'Folomo is coming today' [Sadler 2006: 77], lit. 'Folomo is in coming today'.

The closest relatives of Looma also know the postposition su/zu 'in', but not the progressive construction of this kind, which is a distinct Looma innovation. The copula ka/ja used in (16) is usually etymologised based on the verb * $k a$ 'be, do, see' [Vydrin 1987: 87].

Another confirmation for the theory of locative periphrasis is the nature of Mande verbs; in almost any language, they can build nominal derivatives by means of simple conversion. In Mende (South-Western Mande), the lexeme tó means both 'see' and 'seeing, sight'. The distinction between the two terminal categories lies in the syntactic position in the clause and the rules of syntactic complementation: for instance, the verb cannot be a dependent constituent of the postposition phrase, nor may it be modified by a definite or referential morpheme. The noun, in its turn, may not attach temporal or aspectual markers (if these are applicable in the 
language). Since, however, verbs and nouns convert into each other without any modification, the hypothesis of interpreting a combination [VN + LOC] as [V + PPM] is rather viable.

Cross-linguistically, nominal periphrasis is a well-known means of constructing new analytic progressives, futures and other tense/aspect meanings. This is exactly the evolution path that is being asserted by scholars of the grammaticalisation theory: in [Bybee \& al. 1994], it is stated that the formation of the imperfective aspect starts with nomino-periphrastic constructions initially marking the progressive, but later extended to meanings of habitual and prospective aspects, altogether forming the imperfective cluster [Bybee \& Dahl 1989: 56f.; Bybee \& al. 1994: 275f.]. Both German Ich bin am Kochen 'I am cooking', lit. 'I am at cooking', and English I am a-waiting, derived from I am at waiting, are exact parallels of this type of periphrastic progressive constructions. English I am going to sing extends the progressive meaning to the (near) future tense. In West Africa, the periphrasis is also in frequent use: besides Claudi's [1994] examples from Ewe, the tense/aspect constructions in Kru languages, geographically adjacent to the Mande area, are mostly explained by means of exactly this kind of periphrasis, with the postulation of the proto-language SVO-type word order [Marchese 1986].

The locative periphrasis hypothesis described above used to be the ruling theory of the genesis of Mande-type verbal constructions, supported by the authority of Bernd Heine. In recent years, however, some critical voices started to appear, challenging the idea of the exclusively verbal origins of Mande predicative markers. At least four papers [Bearth 1995; Creissels 1997a, b; Kastenholz 2003] revised the views described by Claudi and proposed their solutions to the problem of the genesis of PSMs and analytic TAM constructions in Mande 3 .

The principal objections expressed in the papers listed above may be summarised as follows:

1. The proto-language SVO-type word order which one has to postulate following the nominal periphrasis theory is never met across Mande. In Kru and Kwa languages mentioned above for typological parallels, it is a frequent syntactic feature: Kru languages, for example, are characterised by the "mixed system" demonstrating both OV and VO patterns, cf. examples from Dewoin (17) and Wobé (18):

(17) $\bar{\jmath} \quad$ ní $p \bar{\imath} \quad$ sãyè

3SG NEG cook meat

'He does not cook meat';

(18) $\bar{j} \quad s \bar{e} \quad g b \bar{u} \quad p \bar{o}$

3SG NEG house build

'He did not build a house' [Marchese 1986: 24] .

No example of a Mande language with a SVO word order can be found, so the projection of this pattern to the Proto-Mande type, as Claudi [1994] implies, seems doubtful from a comparative point of view. She presents some evidence suggesting remnants of $\mathrm{VO}$ order in Mande, but Kastenholz [2003: 38] is right to call the given data incorrect. So, Creissels is right to note [1997a: 8] that

${ }^{3}$ It should be mentioned that none of the four papers consider the whole of Mande family: Creissels restricts his research to the Mande group, Kastenholz only analyses Western Mande (Manden, Vai-Kono, and Mokole groups), Bearth limits his analysis to Southern Mande.

${ }^{4}$ Cf. a similar case of Songhai demonstrating a gradual diachronic shift of word-order type [Creissels 1997b: 8]. 
"one must assume that this shift from SVOX to SOVX took place very early in the history of the Mande languages, since the order OV suffers no exception in the syntax of the present-day Mande languages"5.

As this statement implies, the idea of reconstructing a feature for the proto-language without finding its reflections in any historical descendant languages will always remain subject to criticism.

2. A substantial share of synchronic Mande PSMs that Claudi [1993, 1994] derives from the reinterpretation of full-fledged verbs do not actually require a locative postposition (PPM) to follow the predicate, so PSM is the only marker of verbal meanings. This is the situation with most aspectual construction in Manden languages, cf. examples from Bambara:

(19a) Mùsó bé táá
woman PROG go
'A woman is going'.

(19b) Mùsó ná táá

woman FUT go

'A woman will go';

(19c) Mùsó ká táá

woman DEB go

'A woman should go' [Creissels 2005].

Claudi explains this phenomenon as loss of the locative element which has become redundant because of the logical stress on PSM as the tense/aspect marker. The same explanation is found in [Marchese 1986] as far as the Kru languages are concerned. In certain languages of the Mande family, PPM indeed tend to shorten and probably lose their segmental value, cf. Tura (Southern Mande) $n \hat{u}-\grave{a}$ 'come-FUT' vs. more archaic (in use back in the 1970s by older speakers) $n \hat{u}-6 \grave{a}$ with the locative postposition $6 a$ 'at' [Bearth 1995: 98].

Naturally, one cannot provide examples for all cases where no PPM is witnessed at the synchronic state because of the lack of historical data.

The second complication is created by those TAM-constructions where no trace of PSM is witnessed, and the grammatical meanings of the verb are expressed solely by PPM. This is the case, for instance, with the stative construction in Maninka and the perfective one in Bambara (both Manden group):

(20) Wo fa-nen sanin na

that fill-PFT gold with

'That was filled with gold' [Hoover 2000: 94];

(21) Mùsó táá-rá

woman go-PFV

'A woman went / has gone' [Creissels 2005].

${ }^{5}$ Heine [1980] supported the idea that the SVO > SOV shift could have taken place back in Niger-Congo, but, unfortunately, I cannot go beyond the scope of the present paper to discuss this suggestion. 
Claudi [1994: 209-212] explains this as the result of PSM deletion, but the data to prove this are insufficient. In languages of the South-Western group, for instance, a number of verbal tense/aspect meanings are expressed by a PPM, while the (obligatory) person marker, occupying the post-subject position, stays in the so called "basic" form, cf. in Bandi:

(22) Ngí lì̀-ngá táa îhu

1SG.BASIC go-PFT town in

'I went to the town' [Heydorn 1940/41].

Provided a PSM once existed between the subject marker and the predicate, it would have been absorbed into a fused morpheme with the former, as it happened in many other constructions in Bandi. Thus, the idea of the full-fledged verb once located in a PSM position seems dubious for Bandi - and for its closest relatives.

Bearth was probably the first to note an important distribution between the "clear" cases of locative periphrasis and more problematic ones. This distribution seems to lie within the morphosyntactic domain:

"Almost all transparent cases of derivation from nominal ... periphrasis are aspectual forms denoting states, action in progression, or contingency, i. e. aspects whose tendency to be expressed by locational metaphors is universally attested” [1995: 112].

To this short list I can also add future action: these four grammatical meanings cover the much larger part of the evidence provided in [Claudi \& Mendel 1991; Claudi 1993, 1994].

In the previous section, I already mentioned cases where the absence of any traces of PSMs prevents the reconstruction of locative sentences: most of these cases mark perfective aspects and past actions as opposed to imperfective aspects and present/future actions. In the South-Western Mande languages of Bandi, Mende, and Zialo, all affirmative past and perfective meanings are expressed by PPMs, while all meanings of the imperfective cluster are indicated by means of a PSM (realised in the form of specific series of fused person markers) plus, optionally, a locative PPM. In Bambara and some other Manden idioms, the perfective aspect is the only meaning expressed by a PPM rather than a PSM. The list of examples may be prolonged.

3. Interestingly enough, Bearth [1995: 115] would challenge one of the principles of grammaticalisation in general:

“... It is difficult to maintain that 'each grammatical morpheme ultimately derives from a lexical word, historically [Claudi \& Mendel 1991: 38]’”.

In saying this, Bearth advocates his view on the deictic origins of the predicative ké marker in Tura, which he traces back to an auxiliary rather than a full-fledged lexeme in the protolanguage. This is in fact connected with the following point of objection, dealing with specific etymologies of predicative markers.

4. Much doubt was cast on the explanation of the origins of some particular PSMs and PPMs in certain Mande languages. A microscope look always reveals cracks. Bearth [1995] presented a detailed analysis of predicative marking in the Tura language, showing that at least some of Tura PPMs may not be derived from postpositions for a phonological reason: while all postpositions in the language carry high, low or (for longer ones) mid-low tone, PPMs show 
mid-high tone. Bearth also challenges the free conversive derivation between nouns and verbs in the proto-language, showing that this is not the case at least in Southern Mande.

Kastenholz [2003], in his turn, rejects the verbal origin of the Manden copulative PSM bé. While Claudi [1994: 204] tends to reconstruct its original meaning as 'to be at', i. e. locational semantics, Kastenholz argues that, according to the synchronic data from Manden tongues, “'to be at'... is not an adequate metalinguistic rendering of the function of bé" [2003: 39]. He also finds the verbal status of the copula doubtful because it is never attested as a fully-fledged verb across Mande.

\subsection{Alternative hypotheses of PSM/PPM genesis}

It was Creissels [1997a, b] who elaborated on an alternative hypothesis to explain complicated cases in Manden languages where the locative periphrasis seems dubious. He suggested (following an earlier idea in [Bird \& Kendall 1986]) that the PSMs are originally nominal postpositions, parts of oblique object phrases which were topicalised and transferred to the left part of the sentence - a general practice widely observed across Mande. This process took place in sentences with stative or any other intransitive verbs, which, subsequently, acquired the transitive perfective meaning. The transformation could have looked as follows:

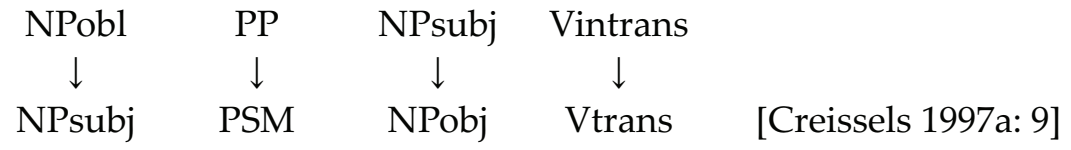

Transition of a stative sentence ("The letter is written", Creissels' example) to a topicalised one ("As for me, the letter is written") and, further, into a perfective one ("I have the letter written") is logically quite possible.

A similar idea was proposed by Creissels based on evidence from hortative constructions. He claims that hortative mood markers (also located in the PSM position in Manden languages) might have originated from postpositions due to reanalysis of the sentence structure. An example from French: A Jacques de jouer 'for Jacques to play' is his explanation of how the postposition phrase may be moved to the beginning of the clause.

In favour of the "postpositional" hypothesis of the PSM origins is the fact that both postpositions and PSMs are always placed following the NP - whether subject or oblique. Moreover, etymologically, the PSMs analysed by Creissels are identical or quite similar to postpositions of the same language. The hypothesis would explain a seemingly weird "split" structure of perfective marking in Manden, where affirmative transitive and all negative clauses use a PSM, whereas affirmative intransitive clauses use a PPM.

At the same time (as he admits himself), against this idea is the absence of prototypical topicalised sentences with an initial postposition phrase in synchronic Manden evidence, and the typological rarity of such constructions in West Africa in general.

Bearth [1995] also recognised the validity of nomino-periphrastic constructions as the source of some of the analytic verbal complexes in the Southern Mande languages of Dan and Tura to which his paper is devoted. At the same time, he rejected the mechanistic interpretation of each and every PSM as a former lexical verb. In his paper, he presents cases of predicative markers from Southern Mande languages that he derives from proto-language sentence deictic morphemes, trying to ground his hypothesis on typological, functional and discourse-pragmatic observations of predicative marking in the language in general. Unfortunately, only very little concrete comparison is given to trace the PSMs of Tura or Dan to their proto-language ancestors: 
Bearth only compares the Tura PSM ké with the identical Soninke morpheme (referring to a NP only), to make a firm conclusion that the marker "goes back to Proto-Mande" [1995: 109].

Kastenholz [2003] seeks more comparative evidence to challenge the idea of the verbal origins of PSMs. Several Western Mande PSMs analysed in his paper are compared with relevant postpositions to find more proof for Creissels' views. Two other morphemes, progressive/imperfective * $b \varepsilon$ and the copulative/progressive * $y e ́$, are traced back to the same copula of a non-verbal, independent origin. The idea that Kastenholz puts into his conclusions is the same as that of both Creissels and Bearth: "we have to assume the possibility of multiple sources" for Mande predicative markers.

Some other views on the non-verbal genesis of PSMs have been expressed. To give an impression of the spectrum of possible etymologies, I will briefly touch upon a few of them.

In the closely related Soso and Jalonke (Western Mande), progressive PPM is surely derived from the nominal lexeme $f e$ 'thing', cf. Soso:

(23) N-ma dii i siga-fe minden?

1SG-POSS child 2SG go-PROG where

'My child, where are you going?' [Plungian \& Urmanchieva 2006].

In Jalonke, the morpheme still preserves nominal characteristics:

(24) A mini fee-n' i a kwi

3SG exit thing-DEF at 3SG in

'It is about to get out of it' [Lüpke 2005: 124].

In the northern dialects of Looma (South-Western Mande), the habitual PSM $d a$ is normally derived from $d a$ 'usually'. The verb is not followed by any PPM, but the imperfective series of person markers is required:

(25) Folomo ra da kale-i be

Folomo 3SG.IPFV HAB fish-DEF catch

'Folomo [usually] fishes' [Prost 1967: 66].

The progressive PSM of Gban (Southern Mande) lé is identical with the adverb 'still, so far' and may well be derived from it [Zheltov 2002: 54] (it is also possible that they both ultimately derive from the same verb).

Omitting some highly suspicious, even though poetic, etymologies of this kind ${ }^{6}$, I should mention that cross-linguistically, the adverbial origin of PSMs is postulated for some Kru languages: e. g., in Grebo temporal markers are all transparent reflections of adverbs of time, which may refer to the past, present or future:

(26) Né dú-da blà

1SG pound-T rice

'I pounded rice the day before yesterday', from $d a$ 'the day before yesterday' [Marchese 1986: 254].

${ }^{6}$ Hamlyn [1935] suggested that the Mandinka potentialis PSM si originates from the adverb sina 'tomorrow', which, in its turn, consists of si 'sun' and na 'come'. 


\section{Implications on Proto-Mande predicative markers}

This discussion is essential to show the main thesis of those who are opposed to Claudi's ideas: their point is not to nullify the hypothesis of the periphrastic origin of TA constructions in Mande, but rather to diversify the sources of their genesis, offering more plausible solutions where the periphrastic theory seems unconvincing. Creissels is absolutely correct when he says:

“Claudi's hypothesis seems quite reasonable, and my purpose is not to challenge it... However, the hypothesis that the category of PM appeared, in the history of the Mande languages, as the result of the decategorialization of ancient auxiliaries does not necessarily imply that the claim that every present day member of this category is the reflex of an ancient auxiliary" [Creissels 1997a: 7-8].

The views described above are essential for any work on reconstructing the shape and meaning of particular predicative morphemes for the Proto-Mande language stage: a task that, so far, has attracted but very limited attention from researchers. The present section will be devoted to the comparison of several markers of tense / aspect and polarity which are attested across the family, and the attempt to establish their proto-language ancestor forms and meanings.

\subsection{Prospective *nà}

The PSM $n a$ is found in various genetic units within the Mande language family as a marker of the action envisaged in the nearest future, or the intention to conduct the action soon. The general meaning can be thus called prospective, though other terms have been used to indicate it as well: ingressive, inchoative, and proximal future.

This is the most frequent meaning I can trace across the family, but not the only one. As it often happens cross-linguistically, the prospective meaning may spread to the progressive or any sort of ongoing action which is to be finished in the nearest future. As such, this marker may encompass the progressive aspect acquiring a more general imperfective value.

(27) A na goro xunbane (Soninke/Soninke-Bozo)

3SG PSM grind tomorrow

'She will grind tomorrow' [Urmanchieva \& Plungian 2006];

(28) Mùsú nà tóbílì là (Kagoro/Manden)

woman PSM cook PPM

'A woman will cook' [Vydrin 2001: 138];

(29) Mùn nà à jó̀̀n dēyn dèyn (Dzuun/Samogo)

1PL.EXCL PSM 3SG eat little little

'We will eat it little by little [Solomiac 2007: 263];

(30) $N$ na dyo mì (Seenku/Samogo)

1SG PSM water drink

'I will drink water' [Prost 1971: 53];

(31) $\grave{A}$ nà dùgó tùgó (Bobo/Bobo)

3SG PSM millet sow

'He will sow millet' [Le Bris \& Prost 1981: 246]. 
In the Manden group, the construction is often finalised by the locative particle la. A sign of a PPM is seen in Bobo where the verb is acquiring a higher tone on the last syllable.

In Vai (Vai-Kono), the construction has not been fully grammaticalised yet, and the marker of the aspectual meaning still acts as an auxiliary verb 'to come', capable of attaching tense/aspect morphemes. The meaning of the construction is again prospective:

$\begin{array}{llllll}\text { Mscnui } & \text { na- } a & \text { salay } & \text { nama } & \text { so } & a \\ \text { people/DEF } & \text { come-FUT } & \text { bridge } & \text { new } & \text { build } & \text { PPM }\end{array}$

'The people are about to build a new bridge' [Heydorn 1971: 179].

The PPM $a$ has an allomorph $d a$ after nasal consonants, which makes it a direct cognate of the Manden PPM above.

According to Welmers' study of Vai, a copulative PSM may also be included into the picture, giving the understanding of a slightly different grammaticalisation path:

(33) $\grave{A}$ bè ná nà kén só nà

3SG COP come PPM house build PPM

'He is going to build a house' [Welmers 1976: 97].

This way of turning an original copulative construction into a prospective verbal form is easily compared with prospective aspect marking in some other Manden languages. There, the prospective meaning is expressed by means of PSMs yénà and bénà which may be derived from a combination of the copula and the auxiliary verb 'to come':

(34) Ń bénà séwérí ké (Dyula/Manden)

1SG PSM something write

'I am going to write something' [Sangaré 1984: 320].

Copulae $b \varepsilon$ and $y \varepsilon / y e$ are used almost everywhere across Manden and Mokole languages in progressive and, in general, imperfective constructions. The widespread semantic overlap between imperfective, progressive and prospective could influence the combined usage of the two markers. It is notable that, while $n a, b \varepsilon$ and $y \varepsilon$ can be used to mark the imperfective cluster of meanings, neither $b \varepsilon$ nor $y \varepsilon$ are used to mark exclusively the prospective meaning.

The marker that may be reconstructed on the basis of the comparanda listed above must have had a low tone: "nà. Its distribution does not allow us to trace it back to Proto-Mande, but only to Proto-Western Mande, with a seeming absence of reliable cognates in the Eastern branch of the family. Moreover, it seems that even in Proto-Western Mande it did not complete the entire process of grammaticalisation, and acted as an auxiliary verb within the analytic construction with a prospective meaning. At least this is what may be suggested, based on data from Vai.

If the PSM was still understood as a verbal lexeme *nà 'to come' in the proto-language, it becomes clear why we are unable to spot it in Eastern Mande. There, the verb *nà 'to come' was replaced by different lexical items which, logically, occupied the position of *nà in prospective constructions. These include ${ }^{*} n \bar{u}$ in Southern Mande and * $p a ́{ }^{*} b a ́$ in South-Western Mande, both of which serve as PSMs in complex constructions with the same meaning.

Now the question arises whether we can reconstruct the second (post-predicate) element of the periphrastic construction for any stage of the proto-language. At this stage, the answer is no: evidence for da/la as the locative PPM in this construction comes from Vai-Kono and Manden groups, but is not found elsewhere. 


\subsection{Negative ${ }^{*} t a /{ }^{*} t e$}

The PSM of negative polarity ta/te/te is found in most groups of Mande languages. In some of them, it undergoes a phonetic alternation and acquires the form la/le/le respectively. Within the clause, the negation PSM usually follows the TAM marker.

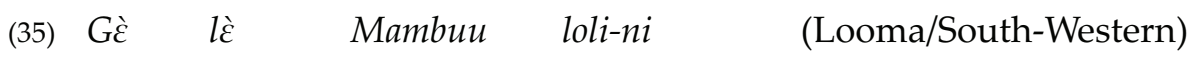

1SG NEG Mambu call-AOR

'I did not call Mambu' [Heydorn 1971: 90];

(36) Ń té kúmá in yàfà (Bambara/Manden)

1SG NEG word/DEF DEM forgive

'I will not forgive these words' [Creissels 2007: 26];

(37) Nè bándánóć wò mòj té kárí yén (Lele/Mokole)

if cloud/DEF be person NEG moon see

'When it is cloudy, nobody [usually] sees the moon' [Vydrin 2009b];

(38) $N$ te so (Bozo/Soninke-Bozo)

1SG NEG come

'I am not coming' (present or future) [Monteil 1932: 302];

(39) Màní láá j́ dō (Mwan/Southern)

Mani NEG 1SG know

'Mani does not know me' [Perekhvalskaya 2006].

We should also note Jeri (Jogo-Jeri) $t \varepsilon$, although I did not find any examples on it [Vydrin 1999: 135].

In languages where the negation strategies depend on aspectual or temporal semantics of the predicate, ${ }^{*} t a /{ }^{*} t \varepsilon$ tends to negate the present tense (as in Bozo) and/or the imperfective aspect (as in Bambara, Lele, Soninke).

Obviously the same morpheme participates in compound PSMs, negating the imperfective aspect in a few Mokole languages: cf. Kakabe bele, Mogofin bélè. The first element of these markers is obviously the same progressive (copula) marker that I mentioned in the previous section.

In Guro (Southern Mande) we observe the IM tē indicating the prohibitive mood; I will allow myself to repeat the example:

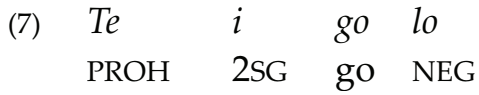

'Do not go (sg.)' [Benoist 1969: 68]

Just as most IMs imply (see above), this is a marker of modality, but it may well be cognate with the PSMs of other Mande languages. The Guro form also gives a clue about the genesis of *ta/*te: it may have originated from a negative verb, in exact accordance with Givón's cross-linguistic observation that negation markers

"most often arise diachronically from erstwhile negative verbs, most commonly 'refuse, deny, reject, avoid, fail' or 'lack'” [1975: 36]. 
Indeed, we can find some confirmations of this grammaticalisation technique in Mande as well: for instance, in Southern Mande negation markers are often derived from Proto-Mande verbs *ban 'deny' and *do 'leave' [Vydrin, ms.]. There are some possible cognates in Mande as well: cf. Bokobaru $t \varepsilon$ 'prohibit, deprive' [Jones 2004b: 173] or Bambara te 'deny, not be'.

In this regard, it would be useful to present some external evidence from Niger-Congo languages, already noted by Greenberg: Proto-Bantu *ta 'not have', Temne, Limba (“Atlantic”) ta 'not be', etc.

A similar, but not identical, idea was expressed by Denis Creissels [1997b]. Discussing negation in the languages of the Manden group, he states that *té acts there not only as an imperfective negation marker, but also as a negative copula in existential sentences. In the Malinke language (dialect of Kita), existential clauses use NTE instead of TE elsewhere in Manden. Creissels takes this form as a combination of ${ }^{*} N$ (negation marker) and ${ }^{*} T E$ (copulative verb 'to be'). The former is explained as a reflection of ${ }^{*} m V$, a well-established negation morpheme mostly used in perfective sentences (see below). The latter is compared with the existential verbs found in Bobo and Bisa, two other Mande languages, as well as, externally, with various 'be'-like verbs, found across Niger-Congo [1997b: 11].

This hypothesis seems to me weaker than the previous one. First of all, from the distribu-

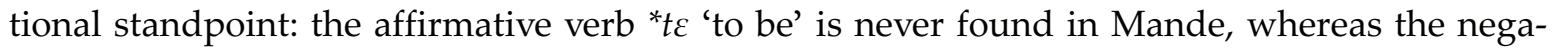
tive meaning is represented quite widely, as shown above. In Bisa, Bobo, and Vai, the existential copula (acting also sometimes as a PSM in imperfective constructions) is ti but never te or $t \varepsilon$ [Tröbs 2003], and I am puzzled at how this $t i$ could be compared with the back-vowel form ta that is found in some groups of Mande. In Niger-Congo languages, the existential verb is found indeed, but, for instance, in Bantu it is reconstructed as *di, which is certainly farther from *ta/ ${ }^{*} t \varepsilon$ than the Bantu negative verb *ta. I do not exclude, however, the possibility of a genetic relationship between * $t i{ }^{*} d i$ 'to be' and *tal*t $t \varepsilon$ 'not to be'.

Another obstacle is the assumption that the ${ }^{*} m V$ negation marker is a part of NTE found in Kita. The nasal element is only found in one dialect of one language, but nowhere else in Manden. We can certainly suggest its early assimilation, but in this case I assume that it would have left traces at least in the system of initial consonant alternations in such languages as SouthWestern Mande, where the proto-language * $n t V$ would have given * $t V$, with a "strong" initial consonant, in all positions. Still, we observe that, following a final vowel of the preceding word, the negation marker there changes into the "weak" form *lV (Bandi là, Kpelle là, Looma lállé).

The combination of ${ }^{*} m V$ and ${ }^{*} t V$ is also not an entirely spotless idea. We should admit that across Manden, there is a distinct differentiation between negation strategies for perfective and imperfective meanings, and * má can certainly be reconstructed only as a perfective negation morpheme for Proto-Manden. Its opposition with *té is strictly adhered to in almost all Manden dialects, and I see no reason in merging the two markers into one.

At the same time, I should note that the form ${ }^{*} n t V$ is also a valid reconstruction: I have found Jeri (Jogo-Jeri) $n d \varepsilon$ (an allomorph of $t \varepsilon$ ) and Soninke ntá which, together with Kita Malinke $n t \varepsilon$, permit us to preliminarily postulate Proto-Western-Mande *ntál*nté. I will not, however, speculate on the origins of the nasal prefix without further evidence.

The evidence seems to be in favour of the reconstruction of ${ }^{*} t a{ }^{*} t \varepsilon$ as the negation marker which was probably grammaticalised from the respective negative verb already in Proto-Mande.

\subsection{Imperfective * $m a$}

The morpheme under discussion in this subsection has been spotted all over Mande. It may be reconstructed as a noun with a locative meaning 'surface, on the surface': this is the 
semantics of the lexeme that we can still observe in some of the tongues of the family (e. g., South-Western, Vai-Kono). In some other languages, however, the noun has already been grammaticalised into a postposition which has lost all nominal functions and may only head an indirect object phrase, cf. Mende tíbii mà 'on the table' [Innes 1971: 64]. The spectrum of meanings has sometimes been extended from mere locative ones, as in Looma:

(40) Bó l̀̀ lù-ì mà

3SG/tell 2SG son-DEF PP

'Tell it to your son' [Sadler 2006: 20].

The appearance of $m a$ as a PPM in imperfective constructions, especially accompanied by the PSM of verbal origin, lies within the framework of the theory of locative periphrasis described above. Such constructions are found in various groups of the family:

(41) Náygà và lì má (Bandi/South-Western)

1SG PSM go PPM

'I am leaving' [Bandi, ms.: II, 10];

(42) A kedi-ye sebe-ma (Soso/Soso-Jalonke)

3SG paper-PL write-PPM

'He [usually] writes letters' [Shluinsky 2006: 332];

(43) Too on summun ma nde! (Jalonke/Soso-Jalonke)

today 1PL chat PPM IRR

'Today we will chat!' [Lüpke 2005: 123];

(44) Mí kpánkà kònò-mò $\quad \eta \bar{e} \quad$ (Seenku/Samogo)

1PL cassave cultivate-PPM NEG

'We do not [usually] cultivate cassava' [Prost 1971: 53] (?);

(45) Kò̀̀ céć i sőrö-mà di (Yaure/Southern)

1PL.EXCL NEG 2SG insult-PPM NEG

'It is not we who will insult you' [Vydrin, ms.: 39];

(46) $\tilde{A} \quad d \tilde{a}$ yì fáánè mà (Guro/Southern)

1SG come day all PPM

'I come every day' [Benoist 1969: 56].

In Zialo (South-Western), postpredicative mà is no longer obligatory. It is still in use in debitive and some progressive constructions, but may well be omitted: an evidence of the gradual loss of PPMs and the focus on PSM as principal temporal/aspectual indicators [Babaev 2011].

The projection of * $m a$ onto the Proto-Mande level seems justifiable, based on comparative data presented above. However, there is always a chance that the imperfective constructions were formed independently in each of the branches at a later stage, using a common locative periphrasis pattern. An indirect proof of the proto-language origins of the imperfective * $m a$ would be the discovery of a language which has lost this morpheme as a postposition, but preserved it as a predicative marker. This is not the case with the list given above: in all these languages, $m a$ is still a productive locative postposition. 


\subsection{Perfective $* d a /{ }^{*} l a$}

This PPM with a perfective meaning is found in a sufficient number of groups to be reconstructed for Proto-Mande. It appears as $d a$ and may alternate with $r a$ or $l a$ in a postvocalic position.

(47) Sǔ bòrì-dà (Malinké/Manden)

horse/DEF run-PPM

'The horse ran' [Creissels 2009: 160];

(48) Mògóórí tágá-rà sènéć rá (Dyula/Manden)

people/DEF leave-PPM field PP

'The people have gone to the field' [Sangaré 1984: 197];

(49) Kaie don-da keye lo (Vai/Vai-Kono)

man enter-PPM house PP

'The man entered the house' [Heydorn 1971: 173];

(50) À kìnj̀̀-rà tèlè fèlà koro (Lele/Mokole)

3SG sleep-PPM day two PP

'He slept for two days' [Vydrin 2009b];

(51) Dio beri-re (Jeri/Jogo-Jeri)

child beat-PPM

'The child is beaten' [Vydrin 1999a: 95].

Apart from this usage, the ${ }^{*} d a /{ }^{*} l a$ form has left some traces in the South-Western Mande perfective PPM *-a which is attested in five of the six languages of the group. The omission of ${ }^{*} l$ - in auxiliary morphemes is a common process in South-Western Mande: cf. the assimilation of copula $l \supset$ into $-\supset$ in Loko and Mende, or the shortening of negative $l a>-a$ in Bandi. The perfective marker ${ }^{*}-a$ in South-Western Mande may be tentatively compared to * $d a{ }^{*} l a$ elsewhere. The same might be true for Mwan (Southern) $-\grave{a}$, again indicating the perfective aspect. It is notable that in Vai, $-a$ is another allomorph of $-d a$ appearing postvocalically: anu jele- $a$ 'they returned' [Heydorn 1971: 173].

Another cognate is found in the grammaticalised perfective PSM of various Western Mande tongues, derived from the finite verbal form of the verb 'to finish':

$$
\text { Mùsà à wòri' bàrà bán (Dyula/Manden) }
$$

Musa 3SG money/DEF PSM finish

'Musa's money has finished' [Braconnier 1989: I, 52];

(53) Xiixsl-la bant' ee suxu (Jalonke/Soso-Jalonke)

Sleep.envy-DEF PSM 3PL seize

'Are they sleepy? (lit. 'Has the wish to sleep taken them?') [Lüpke 2005: 124];

Note also ara/bara in Koranko (Mokole) [Kastenholz 1987], to complete the picture. Vydrin [1999b] reconstructs the protoform of this perfective marker as *ban-Da; I would probably 
postulate *ban-da and admit that we have enough evidence to reconstruct Proto-WesternMande ${ }^{*} d a$ as the perfective PPM.

Its origin from the locative noun *da 'place', attested across Western Mande, is a probable hypothesis. If we accept the witty idea of Creissels that postpositions might reappear as PSMs following the topicalisation of indirect object phrases, this allows us to explain two cases of ${ }^{*} d a$ in the PSM position: in Soninke (Soninke-Bozo) (54), and in Kpelle (South-Western) (55):

(54) A da yinbe lo kurukurun wa 3SG PSM fire let granary PP

'He has burned the granary' (lit. 'He has let the fire into the granary') [Urmanchieva \& Plungian 2006];

(55) Nà-á Pépèè wò béláá káá

1SG-PSM Pepe POSS sheep see

'I have seen Pepe's sheep' [Konoshenko 2009].

In Kpelle, the perfective morpheme á (Liberian $\hat{a}$ ) has almost merged with the person marker; however, in Liberian dialects it still shows no fusion process and may be regarded as a syntactically separate morpheme comparable with PPM * $a$ in other South-Western Mande languages.

I do not have enough evidence from Eastern Mande languages to supplement the evidence given above. Perfective PPMs are frequently found as $-a$, but I have no confirmation that this form should belong to the same cognate set. For the moment, I have to limit the reconstruction to Proto-Western-Mande.

\subsection{Perfective negative *má}

This PSM is also reconstructible for Proto-Western Mande on the basis of evidence from Manden, Mokole, Jogo-Jeri, Vai-Kono, Soninke-Bozo, and Bobo:

(56) Sékú má tìgà sènè (Bambara/Manden)

Sekou PSM ground.nut cultivate

'Sekou did not cultivate ground nut' [Creissels 2007];

(57) À máá nàà kúnún (Kakabe/Mokole)

3SG PSM come yesterday

'He did not come yesterday' [Vydrina 2008: 18];

(58) Bakari ma daga Bamako (Soninke/Soninke-Bozo)

Bakari PSM go Bamako

'Bakari did not go to Bamako' [Soninke, ms.: 150];

(59) Mù má kì béc̀nà (Vai/Vai-Kono)

1PL PSM sleep well

'We did not sleep well' [Welmers 1976: 84].

(60) $\grave{A}$ má bèrè gá (Bobo)

3SG PSM fall NEG

'It did not fall' [Le Bris \& Prost 1981: 232]. 
Phonetically, dialectal variants of this morpheme occur as mo, maa, but the diversity is not wide. The semantics of this marker is also quite uniform, covering meanings of the perfect, the aorist, the general past tense (preterite), etc. In Bozo (Soninke-Bozo) and Jeri (Jogo-Jeri), this PSM is in use in subjunctive, dependent clauses, in Jeri also in conditional ones. In Soso (Soso-Jalonke), the meaning of $m \bar{a}$ is primarily prohibitive. The whole cluster of these meanings, therefore, may be called «irrealis»: quite a widespread grammeme in Mande and, beyond that, in West African languages.

In Manden, Mokole and some other languages the perfective / irrealis meanings of this PSM are accompanied by the existential sense - má acts as a copula:

(61) Sila ma dyana

road COP long

'The road is not long' [Ellenberg, ms.].

The genesis of *má, which is a reliable Proto-Western Mande root, is unclear. In Maninka, the perfective negation marker is man / man (variable tone), possibly a retention of a protolanguage triphonemic form. I did not manage to find a reliable lexical source for this marker, and would rather postulate it as a negative copula for Proto-Western Mande already.

\section{Conclusions}

These preliminary remarks aim at summarising the hypotheses and views on the origins of predicative markers in Mande, and at proposing a very short inventory of morphemes that look as more or less reliable candidates for the proto-language.

Descending onto group level, we predictably find more cognates and thus, more opportunities for successful reconstruction. Tröbs [2003] has showed much uniformity in imperfective markers and existential copulas in Manden, and some of his conclusions may probably be projected onto a higher level (although hardly onto Proto-Western Mande). The drastic reduction of morphemic form in Eastern Mande (especially Southern Mande languages) has led to the V-shape of the majority of markers or, even further, turned them into suprasegmental morphemes. This makes me quite cautious concerning the interpretation of any Eastern Mande evidence, and therefore, prevents me from postulating Proto-Mande markers. A more thorough study of tonal correspondences between auxiliaries in various Mande groups will inevitably present more interesting comparative conclusions.

Finally, it is highly advisable to look more attentively for external comparative data, an issue I have touched upon only briefly, for lack of space. Morphemes such as predicative markers do not migrate across areal language unions, and similarities between the families are almost always due to genetic relationship. Comparing the Mande data listed above with the available data in neighbouring and especially distant Niger-Congo languages, such as Ijoid, Bantu, or Kordofanian, may provide more evidence for their Proto-Mande origins.

\section{List of Abbreviations}

$\begin{array}{llllll}\text { AOR } & \text { aorist } & \text { DEM } & \text { demonstrative } & \text { HORT } & \text { hortative } \\ \text { COP } & \text { copula } & \text { EXCL } & \text { exclusive } & \text { IM } & \text { initial marker } \\ \text { DEB } & \text { debitive } & \text { FUT } & \text { future } & \text { INCL } & \text { inclusive } \\ \text { DEF } & \text { definite marker } & \text { HAB } & \text { habitual } & \text { IPF } & \text { imperfect }\end{array}$




$\begin{array}{llllll}\text { IPFV } & \text { imperfective } & \text { PL } & \text { plural } & \text { PROSP } & \text { prospective } \\ \text { IRR } & \text { irrealis marker } & \text { PM } & \text { predicative marker } & \text { PSM } & \text { post-subject marker } \\ \text { LOC } & \text { locative } & \text { POSS } & \text { possessive } & \text { RES } & \text { resultative } \\ \text { NEG } & \text { negation marker } & \text { PP } & \text { postposition } & \text { SG } & \text { singular } \\ \text { OPT } & \text { optative } & \text { PPM } & \text { post-predicate marker } & \text { T } & \text { tense marker } \\ \text { PFT } & \text { perfect } & \text { PROG } & \text { progressive } & \text { TAM } & \text { tense/aspect and modality } \\ \text { PFV } & \text { perfective } & \text { PROH } & \text { prohibitive } & & \end{array}$

\section{Literature}

(A Bandi Grammar). Manuscript. Monrovia: The Institute for Liberian languages. Vols. I-II.

AmeKA, F. \& M. E. Kropp DAKubu (eds). 2008. Aspect and Modality in Kwa Languages. Amsterdam \& Philadelphia: John Benjamins.

ANYANWU, R.-J. 2010. Tense, Aspect, and Mood in Benue-Congo Languages. Köln: Rüdiger Köppe.

BABAEV, K. 2011. Zialo: The Newly Discovered Mande Language of Guinea. München: LINCOM Europa.

BEARTH, T. 1995. Nominal periphrases and the origin of the predicative marker in Mande languages - an alternative view. Afrikanistische Arbeitspapiere 41: 89-117.

BENOIST, J.-P. 1969. Grammaire gouro. Lyon: Afrique et Langage.

BIMSON, K.D. 1978. Comparative Reconstruction of Proto-Northern-Western Mande. Ph.D. Thesis. Los Angeles: University of California.

BIRD, C. \& M. Kendall. 1986. Postpositions and auxiliaries in Northern Mande: syntactic indeterminacy and linguistic analysis. Anthropological Linguistics 28 (4): 389-403.

Braconnier, C. 1989. Dioula d'Odienne (Parler de Samatiguila): Dictionnaire et études de linguistique déscriptive. Thèse pour le doctorat d'etat. Grénoble: Université de Grénoble III.

BybeE, J. \& Ö. DAHL. 1989. The creation of tense and aspect systems in the languages of the world. Studies in Language 13,1: 51-103.

Bybee, J., Perkins, R. \& W. PAgliUCA. 1994. The evolution of grammar: aspect, tense and modality in the languages of the world. Chicago \& London: University of Chicago.

Claudi, U. \& D. Mendel. 1991. Noun/verb distinction in Egyptian Coptic and Mande: a grammaticalization perspective. Ägypten im afro-orientalischen Kontext. Afrikanistische Arbeitspapiere. Köln: Institut für Afrikanistik. Pp. 31-53.

Claudi, U. 1993. Die Stellung von Verb und Objekt in Niger-Kongo-Sprachen. Ein Beitrag zur Rekonstruktion historischer Syntax. (Afrikanistische Monographien, 1). Cologne: University of Cologne.

Claudi, U. 1994. Word order change as category change. PAGLIUCA, W. (ed.). Perspectives on grammaticalization. Amsterdam-Philadelphia: John Benjamins. Pp. 191-231.

CREISSELS, D. 1997a. Postpositions as a possible origin of certain predicative markers in Mande. Afrikanistische Arbeitspapiere 50: 5-17.

CREISSELS, D. 1997b. Une tentative d'explication de particularités typologiques de la négation en mandingue. Mandenkan 32: 3-21.

CREISSELS, D. 2005. A typology of subject and object markers in African languages. E. K. E. Voeltz (ed.). Studies in African languages typology. Amsterdam - Philadelphia: John Benjamins. Pp. 445-459.

CREISSELS, D. 2007. A sketch of Bambara argument structure. Workshop on Grammar and Processing of Verbal Arguments. Leipzig, 20-21 April, 2007.

CReISSELS, D. 2009. Le malinké de Kita. Un parler mandingue de l'ouest du Mali. Köln: Rüdiger Köppe.

DWYER, D. 1987-88. Towards Proto-Mande Morphology. Mandenkan, no. 14/15. Pp. 139-152.

ELLENBERG. Maninka-English Dictionary. Manuscript.

FLEISCH, A. 2000. Lucazi Grammar. Köln: Rüdiger Köppe.

GIVÓN, T. 1975. Negation in languages: pragmatics, function, ontology. Stanford Working Papers in Universals 18: 58-116.

GrÉGOIRE, Claire. 1988. An Attempt to Reconstruct Labial Consonants in Mande. DOMINICY, M. \& J. DOR (eds). Phonological reconstruction, problems and methods. Belgian Journal of Linguistics, 3. Bruxelles: Edtitions de l'Université de Bruxelles. Pp. 101-155. 
Hamlyn, W. T. 1935. A short study of the Western Mandinka language. London: The Crown Agents for the Colonies.

HeINE, B. 1980. Language typology and linguistic reconstruction: The Niger-Congo case. Journal of African Languages and Linguistics 2: 95-112.

HeINe, B. \& D. NURSE (eds). 2000. African Languages - An Introduction. Cambridge: Cambridge University press.

HeINE, B. \& D. NuRSE (eds). 2008. A Linguistic Geography of Africa. Cambridge: University Press.

HeINE, B. \& M. REH. 1984. Grammaticalization and Reanalysis in African Languages. Hamburg: Buske.

HEYDORN, R. 1940/41. Die Sprache der Bandi im nordwestlichen Liberia. Zeitschrift für Eingeborenen-Sprachen. Vol. 2. Pp.81-114, 188-217.

HeYdorn, R. 1971. The Vai language in Liberia. Afrika und Übersee, Band 54. Pp. 149-205.

Hoover, C.L. 2000. Tense and Aspect. Maninka Narrative Discourse. M.A. Thesis. Arlington: Univ. of Texas.

INNES, G. 1969. A Mende-English Dictionary. Cambridge: Cambridge University Press.

INNES, G. 1971. A Practical Introduction to Mende. London: School of Oriental and Classical Studies.

JONES, R. 2004a. Boko Dictionary. München: LINCOM Europa.

JONES, R. 2004b. Bokobaru Dictionary. München: LINCOM Europa.

KastenhOlZ, R. 1987. Das Koranko. Ein Beitrag zur Erforschung der Nord-Mande-Sprachen. Bonn: Mundus.

KASTENHOLZ, R. 1996. Sprachgeschichte im West-Mande. Methoden und Rekonstruktionen. Köln: Rüdiger Köppe Verlag, $1996,281 \mathrm{~S}$.

KASTENHOlZ, R. 2003. Auxiliaries, grammaticalization, and word order in Mande. Journal of African Languages and Linguistics, 24: 31-53.

KIMBALL, L. 1983. A Description of the Grammar of Loko. Freetown: Institute for Sierra Leonean Languages.

Konoshenko, M. 2009. Tonal Systems of nouns in Guinean and Liberian Kpelle. Исследования по языкам Африки, вып. 3 [Issledovaniya po yazykam Afriki, 3]. P. 169-176.

LE BRIS, P \& A. Prost. 1981. Dictionnaire bobo-francais. Paris: SELAF.

LeIDEnfrost, T. \& J. MCKAY. 2005. Kpelle-English Dictionary with a Grammar Sketch and English-Kpelle Finderlist. Moscow (USA): Palaverhut Press.

LONG, R. 1971. A Comparative Study of the Northern Mande Languages. Ph.D. Thesis. Bloomington: Indiana University.

LÜPKE, F. 2005. A grammar of Jalonke argument structure. Ph.D. Thesis. Nijmegen: Radboud Universiteit.

MARCHESE, L. 1986. Tense, Aspect and the Development of Auxiliaries in Kru Languages. Arlington: University of Texas.

MonteIL, C. 1932. La Langue des Bozo: Population de pêcheurs du Niger. Pp. 261-317.

NurSE, D. 2007. Tense and Aspect in Bantu. Oxford: Oxford University Press.

PereKhVAlsKayA, E. 2006. The verbal system of Mwan. Papers of the Institute of Linguistic Research. Vol. 2, part 2. St.Petersburg: Nauka. Pp. 296-322. [Перехвальская, Е. В. 2006. Глагольная морфонология языка муан. // Труды Института лингвистических исследований. Т. 2, Ч. 2. СПб: «Наука». Стр. 296-322.]

Plungian, V. \& A. URmanchieva. 2006. To the description of the verbal system of Soso (compared to Jalonke). Vinogradov, V. \& A. Koval (eds). Papers on African Languages - 2005. Moscow: Institute of Linguistics for the Russian Academy of Sciences. Рp. 187-202. [В. А. Плунгян, А. Ю. УРмАНчИЕвА. К описанию глагольной системы языка сусу (в сопоставлении с джалонке) // В. А. ВИНОГРАДОВ, А. И. КОВАль (ред.). Исследования по языкам Африки - 2005. М.: ИЯз РАН, 2006, 187-202.]

POZDNIAKOV, K. 1978. The Mande languages: A comparative and historical analysis. Ph.D. thesis. Moscow: Institute of Linguistics for the Academy of Sciences of the USSR. [К. И. Поздняков. Языки манде: Сравнительноисторический анализ. Кандидатская диссертация. М.: Ин-т языкознания АН СССР, 1978.]

Prost, A. 1967. Lé loghoma, esquisse grammaticale suivie de textes et d'un glossaire. Documents linguistiques, no. 13. Dakar: Institut fondamental de l'Afrique Noire.

Prost, A. 1971. Eléments de sembla: phonologie, grammaire, lexique. Afrique et langage: Documents, 5. Lyon.

Prost, A. 1976. Essai de description grammaticale de la langue boko ou boussa de Ségbana (Dahomey). Abidjan: Ann. Univ. Abidjan, série H, t. IX.

SADLER, W. 2006 [1949]. A complete analysis of the Looma language. Mandenkan, 42, 2006 [1949]. Pp. 5-109.

SANGARE, A. 1984. Dioula de Kong (Côte d'Ivoire): phonologie, grammaire, lexique et textes. Thèse de 3ème cycle. Grénoble: Univ. de Grénoble III.

SCHreIber, H. 2008. Copula Constructions. Mande: a Preliminary Overview. Mandenkan 44, pp. 63-77.

SHLUINSKY, A. 2006. A polysemy habitualis - futurum: marker -ma in Soso. Papers on African languages - 2005. Moscow: Institute of Linguistics for the Russian Academy of Sciences. Рp. 332-344. [ШиУИНСКИЙ, А. Б. 2006. 
Полисемия хабитуалис-футурум: показатель -та в языке сусу // Исследования по языкам Африки - 2005. М.: ИЯ РАН. СТр. 332-344.]

SolomiaC, P. 2007. Phonologie et morphosyntaxe du dzuungoo de Samogohiri. Thèse doctorale. Lyon: Université Lumière Lyon 2.

Soninke-French-English Dictionary. Manuscript. Asawan Library, http://www.asawan.org/

TRÖBS, H. 2003. On the origin of some predicative markers in imperfective constructions. Manding. Mandenkan no $38-$ p. $1-14$.

Urmanchieva, A. \& V. Plungian. 2006. The verbal system of Soninke: grammatical variation and dialectal diversity. Papers of African languages - 2005. Moscow: Institute of Linguistics for the Russian Academy of Sciences. Рp. 187-203. [УРмАнчИЕВА, А. Ю., В. А. Плунгян. 2006. Глагольная система сонинке: грамматическая вариативность и диалектное членение // Исследования по языкам Африки - 2005. М.: ИЯ РАН. Стр. 187203.]

Vydrin, V. 1987. The Looma Language. Moscow: Nauka. [ВыдРин В. Ф. 1987. Язык лоома. Москва: Наука.]

VYDRIN, V. 2001. Esquisse contrastive du kagoro (Manding). Köln: Rüdiger Köppe.

VYDRIN, V. 2006a. On the Reconstruction of the Phonological Type and Nominal Morphology of Proto-Mande. Works of the Institute of Linguistic Research, vol. 2, no. 2. Pр. 9-252. St. Petersburg: Nauka. [ВЫДРИН, В. Ф. К реконструкции фонологического типа и именной морфологии пра-манде // Труды Института хингвистических исследований. Т. II, ч. 2. СПб., 2006. Стр. 9-252.]

Vydrin, V. 2006b. Personal Pronouns in South Mande. Works of the Institute of Linguistic Research, vol. 2, no. 2. Pp. 327-413. St. Petersburg: Nauka. [Выдрин, В. Ф. Личные местоимения в южных языках манде // Труды Института лингвистических исследований. Т. 2, ч. 2. СПб: Наука. Стр. 327-413.]

VYDRIN, V. 2007. South Mande reconstruction: Initial consonants. Aspects of comparative linguistics 2 [Acneкmbl koмпаративистики 2]. Orientalia et classica XI: Труды Института восточных культур и античности. Моscow, 2007. C. 409-498.

Vydrin, V. 2008. The Bamana language: A manual. St.Petersburg: St.Petersburg University. [ВЫДРИН, В. Ф. 2008. Язык бамана: Учебное пособие. СПб: СПбГУ.]

Vydrin, V. 2009a. On the Problem of the Proto-Mande Homeland. Journal of Language Relationship, vol. 1. Pp. 107-142. VYDRIN, V. Negation in South Mande. Manuscript.

VyDrinA, A. 2008. The phonological system of Kakabe. St.-Petersburg: St.Petersburg University. [ВЫДРИНА, А. В. 2008. Фонологическая система языка какабе. Курсовая работа. СПб: СПбГУ.]

VydRINE, V. 1999. Compte-rendu: Holger Tröbs. Funktionale Sprachbeschreibung des Jeli (West-Mande). Mande languages and linguistics; Vol. 3. Köln: Köppe, 1998. Mandenkan 35: 95-99.

VYDRINE, V. 2009b. Esquisse de la langue lélé (groupe mokolé). Mandenkan no 45. P. 29-104.

Welmers, W. 1973. African Language Structures. Berkeley - Los Angeles - London: University of California.

WeLmers, W. 1976. A Grammar of Vai. Berkeley: Univ. of California.

ZHELTOV, A. 2002. Syntax, deixis and pragmatics: grammar with no borders or super-flectivity in an analytic language (a brief sketch of the verbal system of Gban). The Southern Mande: Linguistics in African Rhythm. Materials of St. Petersburg Expedition to Cote d'Ivoire. St. Petersburg: Evropejskij Dom. Pp. 39-61. [ЖЕлTОВ, А. Ю. 2002. Синтаксис, дейксис и прагматика: грамматика без границ или суперфлективность в аналитическом языке (краткий очерк глагольной системы языка гбан) // Южные манде: Аингвистика в африканских ритмах. Материаль петербургской экспедиции в Кот д’Ивуар. СПб: «Европейский Дом». С. 39-61.]

В статье обсуждаются вопросы происхождения и диахронического развития грамматических показателей времени / аспекта, наклонения и отрицания глагола в языках семьи манде (Западная Африка). Работа содержит обзор гипотез и точек зрения относительно генезиса глагольных предложений в языках манде с точки зрения типологии, а также пробную реконструкцию некоторых грамматических показателей глагола в праязыке семьи манде или их лексические источники.

Ключевые слова: реконструкция, сравнение, языки манде, языки нигер-конго, африканские языки, праязык, время, аспект, наклонение, полярность, грамматические показатели, глагольная система 
